\title{
PHARMACOLOGICAL CLASSIFICATION OF TOXIC PROTEINS FROM SNAKE VENOMS
}

\author{
Chen-Yuan Lee \\ Received for publication 25 June 1975
}

\begin{abstract}
Toxic proteins in snake venoms are classified according to their principal pharmacological properties as follows: 1) Neurotoxins - postsynaptic neurotoxins from elapid and sea snake venoms and presynaptic neurotoxins from some elapid and crotalus venoms. 2) Myotoxins - Cardiotoxins from elapid venoms and crotamine and other basic proteins from crotalus venoms. 3) Toxic proteins acting on blood vessels and other smooth muscle organs - vasculotoxins, hemorrhagins, and bradykinin-releasing esterases from viperid and crotalid venoms, and phospholipase A from most snake venoms. 4) Local necrotizing agents - proteolytic enzymes from crotalid and viperid venoms and cardiotoxins from elapid venoms. 5) Coagulants - Factor X activators, prothrombin activators and thrombin-like enzymes. 6) Anticoagulants inactivation of thromboplastin, Factor $\mathrm{V}$ and prothrombin, and fibrinolytic enzymes.
\end{abstract}

Toxic proteins in snake venoms may be grouped into the following six categories according to their principal pharmacological proterties.

\section{Neurotoxins}

Although the term "neurotoxins" (NTXs) is ill-defined and may lead to confusion, the NTXs from elapid and sea-snake venoms have been shown to act selectively on the neuromuscular $(\mathrm{N}-\mathrm{M})$ junction without any marked effects on other organ systems including the central nervous system (cf. 20, 22). All of the NTXs from elapid and sea-snake venoms are basic polypeptides and devoic of any known enzymic activity. They can be classified into two distinct groups: "postsynaptic toxins" and "presynaptic toxins". Cobra NTXs, $\alpha$-bungarotoxin and sea-snake NTXs belong to the former, while $\beta$-bungarotoxin belongs to the latter. The postsynaptic toxins are composed of either 61-62 or 71-74 amino acid residues in a single chain cross-linked by four or five disulfide bridges, respectively. In spite of the difference in their number of amino acid residues, striking similarities in their primary and secondary structures are found among these toxins. In contrast, the amino acid composition of $\beta$-bungarotoxin is quite different from that of postsynaptic toxins.

Postsynaptic NTXs produce anti-depolarizing N-M block by combining specifi-

Pharmacological Institute, College of Medicine, National Taiwan University, Taipei, Taiwan, China. 
cally with cholinergic receptors on motor endplates. These NTXs also act as specific antagonists at cholinergic receptors on the electric tissue membrane. Pretreatment with d-tubocurarine, $\mathrm{C}_{10}$, $\mathrm{ACh}$ or carbachol protects the receptor against binding of these NTXs. Both axonal conduction of the motor nerve and electrical properties of the muscle membrane are unaffected. Unlike NTXs with 61-62 residues, $\alpha$-bungarotoxin and cobra NTXs with 71 residues block $\mathrm{N}-\mathrm{M}$ transmission irreversibly in most preparations, probably due to richness in hydrophobic amino acids in their molecules. Because of its specific and irreversible nature of the receptor binding, $\alpha$-bungarotoxin has been extensively used for characterization and isolation of cholinergic receptors $(1,9,10,26)$.

Presynaptic NTXs, as exemplified by $\beta$-bungarotoxin, produce an irreversible $\mathrm{N}-\mathrm{M}$ block by depressing ACh release from motor nerve endings, leaving the sensitivity of endplates to $\mathrm{ACh}$ unaffected. The reduction of $\mathrm{ACh}$ release by $\beta$-bungarotoxin is preceded by a facilitated release of transmitter and an increased frequency of miniature endplate potentials (MEPP). This inhibitory effect of $\beta$-bungarotoxin on the release mechanism is delayed when the nerve activity is decreased; e.g. decreased rate of nerve stimulation, decrease in calcium concentration or increase in magnesium concentration in the bathing medium. As in the Mg-induced paralysis, the amplitude of EPPs on repetitive stimulation is rather sustained, suggesting the failure of release mechanism. After complete $\mathrm{N}-\mathrm{M}$ block, the store of $\mathrm{ACh}$ in the rat diaphragm is not reduced. Ineffectiveness of choline as an antagonist and unaltered uptake of choline in the rat diaphragm treated with $\beta$-bungarotoxin exclude the possible involvement of a hemicholinium-like action. In the diaphragm of mice injected with $\beta$-bungarotoxin, synaptic vesicles have been shown to be markedly depleted (11). However, no appreciable change can be found in the hemidiaphragm, if its phrenic nerve has been cut before injection of the toxin (Lee et al., unpublished). These findings indicate that an additional factor such as a high rate of phrenic discharges is required for depletion of synaptic vesicles by the toxin.

Viperotoxin isolated from Vipera palestinae venom has been claimed to be a NTX which acts primarily on medullary vasopressor centers leading to lethal circulatory failure (cf. 14). It remains to be proven, however, that such a basic protein can pass through the blood-brain barrier in sufficient quantity to produce central effects.

\section{Myотохins}

Cardiotoxin (CTX), direct lytic factor (DLF), cobramine, cytotoxin and toxin $\gamma$ are all strongly basic polypeptides isolated from various cobra venoms (cf. 22). Recent evidence indicates that they are either identical or at least a family of homologous toxins. They are composed of 60-61 amino acid residues in a single chain crosslinked by four disulfide bonds.

Cardiotoxin affects various kinds of cells, causing irreversible depolarization of the cell membrane. It produces contracture of skeletal muscle, blockade of axonal conduction and systolic arrest of the isolated heart. These effects are inhib- 
ited by high $\mathrm{Ca}^{++}$and potentiated by phospholipase $\mathrm{A}(\mathrm{PhA})$ which by itself has little effect on these preparations. CTX is by itself only weakly hemolytic, but acts synergistically with PhA. The local irritant action as well as the cytotoxic effect of CTX may account for the local tissue damage observed in cobra bite (18).

Besides cobra venoms, some of the elapid venoms (e.g. Bungarus fasciatus, coral snakes) appear to contain CTX-like principles (24, 37).

Crotamine is also a strongly basic polypeptide toxin, isolated from the venom of Crotalus durissus crotaminicus. It consists of 46 amino acid residues, including four half-cystines. It resembles cobra CTX in its very high lysine (11 residues) and low arginine (2 residues) contents but unlike cobra CTX, it is devoid of threonine, alanine and valine (17). Although crotamine has been classified as a NTX (cf. 7), its pharmacological properties are quite different from those of NTXs, and it may be better classified as a myotoxin.

Crotamine induces an immediate contracture followed by spontaneous and irregular contractions of skeletal muscles of the rat. This effect is inhibited by tetrodotoxin, $\mathrm{Ca}^{++}, \mathrm{Mg}^{++}$and $\mathrm{K}^{+}$, but only partly by curarization or chronic denervation $(7,12)$. The mode of action has not been fully elucidated, but a change in $\mathrm{Ca}^{++}$or $\mathrm{Na}^{+}$permeability on the muscle membrane has been postulated. On the other hand, its stimulant effect on skeletal muscles of baby chicken has recently be shown to be presynaptic in origin (Lee, unpublished).

Like crotamine, the basic proteins isolated from the venoms of Crotalus adamanteus, Crotalus v. viridis, and Crotalus $h$. horridus have a stimulant effect on skeletal muscles of the rat as well as of the baby chicken. The site of action appears to be on the muscle membrane for the former while on the nerve terminal for the latter (23). Of special interest is the finding that the basic proteins from $C$. adamanteus and $C . h$. atricaudatus produce myocardial damage in mice, leading to elevation of serum enzyme levels (4).

\section{iII. Toxic Proteins Acting on Blood Vessles and Other Smooth Muscle Organs}

Vasoculotoxins The heated venom of Vipera russellii produces a long-lasting hypotension which appears to be peripheral in origin (19). Although the active toxin has not been purified, it is postulated that the venom contains some vasculotoxin which causes direct vasodilatation. Viperotoxin isolated from Viper palestinae might also belong to this category.

Hemorrhagins Previously, the hemorrhagins HR1, HR2a and HR2b, isolated from Trimeresurus flavoviridis venom, have been claimed to be devoid of proteolytic activity $(28,36)$. A recent study, however, reveals that HR1, HR2a and HR2b all can liberated Folin-positive material from kidney basement membranes (27). Therefore, evidence is strengthened that hemorrhage is due to proteolytic weakening of the stabilizing apparatus (i.e. the basement membrane and the perivascular fibrils) of the small vessels.

The hemorrhage produced by Naja naja venom on the lung surface capillaries has been attributed to a synergistic action of DLF and PhA (5). 
Bradykinin-releasing esterases Bradykinin, a nonapeptide with powerful hypotensive and smooth muscle-stimulating properties, is regarded as the mediator in the venom-induced, abrupt hypotension. It is released from bradykininogen, a plasma $\gamma$-globulin precursor, mostly by crotalid and viperid venoms (15), but exceptionally by Ophiophagus hannah venom (25). The bradykinin-releasing activity has been attributed to a specific arginine-ester hydrolase (35).

Phospholipase A (PhA) This enzyme may cause various pathophysiological effects, by releasing autopharmacologic substances, such as histamine, serotonin and slow-reacting substance (SRS-C). Some of the hemodynamic efrects as well as the action on smooth muscle of cobra venom can be attributed to PhA (21). Besides, as already mentioned, PhA exhibits synergistic effects with CTX (DLF).

\section{Local Necrotizing Agents}

The main evidence for ascribing the necrotic effect of snake venoms to proteolytic enzymes was the high protease content of many crotalid and viperid venoms endowed with this action and the lack of proteases in elapid venoms, the majority of which do not evoke this effect. Local necrosis produced by cobra venom, however, is attributable to CTX, possibly potentiated by $\mathrm{PhA}(18)$.

\section{Coagulants}

Coagulant effects are exhibited in snake venoms according to the following mechanisms:

1. Factor X activator An arginine-esterase of molecular weight over 100,000 has been purified from Vipera russellii venom $(34,38)$. It splits off from purified plasma Factor X, a strongly coagulant derivative ( FXa) that is by itself an esterase. 2. Prothrombin activator (a) Complete prothrombin activator (conversion of prothrombin to thrombin without Factor V). A poweful procoagulant which promotes the conversion of prothrombin to thrombin has been purified from Echis carinatus (33). It is an acidic protein (M. W. 86,000) and possesses some proteolytic activity. (b) An incomplete prothrombin activator (conversion of prothrombin to thrombin in the presence of Factor V) has been found in the venoms of Notechis scutatus (tiger snake) and Acanthophis antarcticus (13).

3. Trombin-like enzyme The homogeneous thrombin-like principles isolated from the venoms of Agkistrodon rhodostoma (16) and Agkistrodon acutus (29) are glycoproteins that resemble thrombin in its molecular weight. But they differ from thrombin in several respects. They are more heat-stable than thrombin $(16,29)$. Both peptides $\mathrm{A}$ and $\mathrm{B}$ are removed from fibrinogen during the formation of fibrin by thrombin, while only peptide $\mathrm{A}$ is removed by reptilase, the thrombin-like enzym of Bothrops jararaca venom (3). Unlike thrombin, they are not inhibited by heparin $(16,29)$. No clot retraction nor factor XIII (Fibrin stabilizing factor) activation is found with the thrombin-like enzyme (29). Arvin, the thrombinlike enzyme from Agkistrodon rhodostoma venom induces a loss of fibrinogen by conversion into fibrin by systemic application (32). It has been used for prophylaxis 
and therapy of thrombosis (2).

\section{Anticoagulants}

A number of mechanisms account for the anticoagulant effects of snake venoms. 1. Inactivation of thromboplastin The components, which can inactivate thromboplastin, have been separated from the venoms of Naja nigricollis (6), Naja naja atra (8) and Agkistrodon acutus (31). The components from cobra venoms exhibit phospholipase A activity, and are thought to be the main anticoagulant through phospholipid destruction.

2. Inactivation of Factor $\mathrm{V}$ The components which can inactivate Factor $\mathrm{V}$ have been separated from the venoms of Naja naja atra (Ouyang and Chen, unpublished) and Agkistrodon acutus (31).

3. Inactivation of prothrombin A principle which can inactivate prothrombin has been purified from Agkistrodon acutus venom (31).

4. Fibrinolysis Fractions which can cause fibrinolysis have also been separated from Agkistrodon acutus venom (30).

\section{REFERENCES}

1) Barnard, E. A., Wieckowski, J. and Chiu, T. H. (1971): Cholinergic receptor molecules and cholinesterase molecules at mouse skeletal muscle junctions, Nature, 234, 207-209

2) Bell, W. R., Pitney, W. R. and Goodwin, J. F. (1968): Therapeutic defibrination in the treatment of thrombotic disease, Lancet, 7541, 490-493

3) Blombäck, B. (1958): Studies on the action of thrombic enzymes on bovine fibrinogen as mesured by N-terminal analysis, Arkiv Kemi,12, 321-335

4) Bonilla, C. A., Fiero, M. K. and Novak, J. (1971): Serum enzyme activities following administration of purified basic proteins from rattlesnake venoms, Chem. Biol. Interactions, 4, 1-10

5) Bonta, I. L., Vincent, J. E. and Noordhoek, J. (1972): The role of direct lytic factor (DLF) and phospholipase-A in the local hemorrhagic effect of Naja naja venom, J. Formosan Med. Assoc., 71, 333-335

6) Soquet, P., Izard, Y., Meaume, J. and Jouannet, M. (1967): Recherches biochimiques et inmunologiques sur le venin des serpents. II. Étude des propriétés enzymatiques et toxiques c'es fractions obtenues par filtration du venin de Naja nigricollis sur sephadex, Ann. Inst. Pasteur, $112,213-235$

7) Brazil, O. V. (1972): Neurotoxins from the south american rattle snake venom, J. Formosan Med. Assoc., 71, 394-400

8) Brisbois, L., Rabinovitch-Mahler, N., Delori, P. and Gillo, L. (1968): Etude des fractions obtenues par chromatographie du venin de Naja naja atra sur sulphoéthyl-sephadex, J. Chromatography, 37, 463-475

9) Chang, C. C., Chen, T. F. and Chuang, S. T. (1973): N, O-di and N, N, O-tri (3H) acetylbungarotoxins as specific labelling agents, Brit. J. Pharmacol., 47, 147-160

10) Changeux, J. P., Kasai, M. and Lee, C. Y. (1970): Use of snake venom toxin to characterize the cholinergic receptor protein, Proc. Nat. Acad. Sci., 67, 1241-1247

11) Chen, I. and Lee, C. Y. (1970): Ultrastructural changes in the motor nerve terminals caused by $\beta$-bungarotoxin, Virchows Arch. Abt. B Zellpath., 6, 318-325

12) Cheymol, J., Gonçalves, J. M., Bourillet, F. and Roch-Arveiller, M. (1971): Action neuro- 
musculaire comparée de la crotamine et du venin de Crotalus durissus terrificus var. crotaminicus. 1. Sur préparations neuromusculaires in situ, Toxicon 9, 279-286

13) Denson, K. W. (1969): Coagulant and anticoagulant action of snake venoms, Toxicon, 7, 5-11

14) de Vries, A. (1971): Research on snake venoms, In Kupt Holim Year Book Vol. 1, 24-36, Tel-Aviv

15) Diniz, C. R. (1968): In Venomous animals and their venoms Vol. 1 ed. Bücherl, W., Buckley, H. and Deulofew, V., Academic, New York, 217-227

16) Esnouf, M. P., and Tunnah, G. W. (1967): The isolation and properties of the thrombinlike activity from Ancistrodon rhodostoma venom, Brit. J. Haemat., 13, 581-590

17) Gonçalves, J. M. and Giglio, J. R. (1964): In Abstract II. 6th Int. Conger. Biochem., New York, 170

18) Lai, M. K., Wen, C. Y. and Lee, C. Y. (1972): Local lesions caused by cardiotoxin isolated from formosan cobra venom, J. Formosan Med. Assoc., 71, 328-332

19) Lee, C. Y. (1948): J. Formosan Med. Assoc., 47, 14

20) (1970): Clin. Toxicol., 3, 457-472

21) (1971): In Neuropoisons Vol. 1, ed. Simpson, L. L., Plenum, New York, 21-70

22) (1972): Chemistry and pharmacology of polypeptide toxins in snake venoms, Ann. Rev. Pharmacol., 12, 265-286

23) Lee, C. Y., Huang, M. C. and Bonilla, C. A. (1973): In Animal and plant toxins ed. Kaiser, E., Wilhelm Goldmann Verlag, München, 173-178

24) Lin, Shiau S. Y., Huang, M. C. and Lee, C. Y. (1972): Isolation of cardiotoxic and neurotoxic principles from the venom of Bungarus fasciatus, J. Formosan Med. Assoc., 71, 350-357

25) Mebs, D. (1968): Vergleichende Enzymuntersuchungen an Schlangengiften unter besonderer Berücksichtigung ihrer Casein-spaltenden Proteasen, Hoppe-Seylers Z. Physiol. Chem., 349, 1115-1125

26) Miledi, R., Molinoff, P., and Potter, L. T. (1971): Isolation of the cholinergic receptor protein of Torpedo electric tissue, Nature 229, 554-556

27) Ohsaka, A. (1973): In Animal and plant toxins, ed. Kaiser, E., Wilhelm Goldmann Verlag, München, 93-98

28) Omori-Satoh, T. and Ohsaka, A. (1970): Purification and some properties of hemorrhagic principle $\mathrm{I}$ in the venom of Trimeresurus flavoviridis, Biochim. Biophys. Acta, 207, 432-444

29) Ouyang, C., Hong, J. S. and Teng, C. M. (1971): Purification and properties of the thrombinlike principle of Agkistrodon acutus venom and its comparison with bovine thrombin, Thromb. Diath. Haemorrh, 26, 224-234

30) Ouyang, C. and Teng, C. M. (1972): Purification and properties of the anticoagulant principle of Agkistrodon acutus venom, Biochim. Biophys. Acta, 278, 155-162

31) Ouyang, C., Teng, C. M. and Hong, J. S. (1972): Purification and properties of the coagulant and anticoagulant principles of Agkistrodon acutus venom, J. Formosan Med. Assoc., 71, 401-407

32) Reid, H. A. and Chan, K. E. (1968): The paradox in therapeutic defibrination, Lancet, 7541, 485-486

33) Schieck, A., Kobnalik, F. and Habermann, E. (1972): The prothrombin-activating principle from Echis carinatus venom. I. Preparation and biochemical properties, Naunyn Schmiedeberg's Arch. Pharmacol., 272, 402-416

34) Schiffman, S., Theodor, I. and Rapaport, S. I. (1969): Separation from Russell's viper venom of one fraction reacting with factor $\mathrm{X}$ and another reacting with factor $\mathrm{V}$. Biochemistry, 8, 1397-1405

35) Suzuki, T. (1966): Separation methods of animal venoms constituents, Mem. Inst. Butantan, 33, 389-409 
36) Takahashi, T. and Ohsaka, A. (1970): A purification and some properties of two hemorrhagic principles (HR2a and HR2b) in the venom of Trimeresurus flavoviridis; complete separation of the principle from proteolytic activity, Biochim. Biophys. Acta, 207, 65-75

37) Weis, R. and McIssac, R. J. (1971): Cardiovascular and muscular effects of venom from coral snake, Micrurus fulvius, Toxicon, 9, 219-228

38) Williams, W. H. and Esnouf, M. P. (1962): The fractionation of Russell's-viper (Vipera russellii) venom with special reference to the coagulant protein, Biochem. J., 84, 52-62 